\title{
THE EFFECT OF STOCK OWNERSHIP AND DIVIDEND POLICY ON EARNINGS QUALITY IN COMPANIES LISTED ON THE JAKARTA ISLAMIC INDEX
}

\author{
Oki Sania Riski ${ }^{1)}$, Rika Lidyah ${ }^{2)}$, Titin Hartini ${ }^{3)}$ \\ ${ }^{1,2,3)}$ The Faculty of Islamic Economics and Business, UIN Raden Fatah Palembang \\ Corresponding author: rikalidyah_uin@radenfatah.ac.id
}

\begin{abstract}
This study aims to determine the effect of stock ownership and dividend policy on earnings quality in companies listed on the Jakarta Islamic Index. This study uses a quantitative research method and uses panel data, combining time-series and cross-sectional data. The samples used in this study were eight companies registered in the Jakarta Islamic Index from 2015 to 2019. The data analysis technique in this study is multiple regression analysis using the SPSS 22 application. The results in this study indicate that partially institutional ownership has a significant effect on earnings quality, managerial ownership has a significant effect on the quality, and dividend policy has no effect on earnings quality.
\end{abstract}

Keywords: Institutional Ownership, Managerial Ownership, Dividend Policy, Earnings Quality

\section{Introduction}

Profit is an essential component for users of financial statements because it can reflect future cash flows obtained by the company. So that companies can distribute dividends to investors and pay their debts to creditors and increase the company's value in the capital market. Profit is also a tool that can measure the company's performance over a certain period. Information on profit is used to measure the success or failure of a business in achieving the stated operating objectives because the company's performance information reflected in profit is important information seen by creditors and investors in making decisions regarding credit and investment and predicting future profits. High-quality earnings are profits that are free from errors and misleading information for users of financial statements. Management in agency theory acts as an agent who represents the principal or owner in managing the company. Earnings quality is an indicator of the quality of financial information and the actual economic performance of the company, not just the performance listed in the financial statements. Therefore, various studies continue to be carried out in order to be able to compile financial reports that have high earnings quality. Earnings quality is an indicator of the quality of financial information and the actual economic performance of the company, not just the performance listed in the financial statements. Therefore, various studies continue to be carried out in order to be able to compile financial reports that have high earnings quality.

Earnings management practices have led to several cases in accounting reporting being widely known. Badan Pemeriksa Keuangan (BPK) revealed that in the preliminary investigation examination, it was found that there was a manipulation of the financial statements of PT. Asuransi Jiwasraya (AJS). It was found that there was profit manipulation of Rp 360.3 billion in 2006. Chairman of BPK Agung Firman Sampurna said it received an adverse or modified opinion at AJS's financial profit opening. If Jiwasraya made a backup at that time, it would see a loss of Rp 15.3 trillion. In 2017, BPK saw a fraudulent provision of Rp 7.7 trillion. If the backup is carried out following the provisions, the company should suffer a loss. Since 2006 PT AJS reported that the company made a profit, but the profit was pseudo due to accounting engineering or window dressing. In 2018 PT AJS then recorded an unaudited loss of Rp. 15.3 trillion, and as of September 2019, it is estimated that PT AJS's loss reached Rp. 13.7 trillion. Then in November 2019, PT AJS is estimated to experience negative equity of IDR 27.2 trillion. The head of the BPK also suspects that there is an activity to change other data or window dressing on sales of the JS Saving Plan product. BPK considered a manipulation during the share sale and purchased transaction by Jiwasraya so that the price of the shares purchased did not reflect the actual price. Due to this action, there are indications of losses related to mutual fund shares at Jiwasraya of up to Rp 6.4 trillion. (www.cnbcindonesia.com ).

A scandalous case of earnings manipulation through published financial statements results in doubts about the reliability of the financial statements, which causes a loss of trust by the public and can lead to a decrease in the market reaction to published earnings. This can indicate a decrease in the quality of the resulting earnings information. A financial scandal that occurred caused a crisis of investor confidence in the capital market. The phenomenon of financial scandals shows that financial statements have failed to meet the information needs of the users of these reports. Earnings, as part of the financial statements that are widely considered by users of the report, do not present facts about the company's economic condition, so that the profit information presented can be detrimental to report users.

Internal factors that affect the opportunities and incentives for management in accounting reporting are related to institutional ownership and managerial ownership at the company level and the auditors chosen by 
the company to audit their financial statements. One of the factors considered to influence earnings quality is dividend policy. Dividend policy is defined as a policy related to dividend payments by the company, determining the number of dividends to be distributed and the amount of balance to be retained for the company's benefit.

\section{Literature Review Agency Theory}

Jensen and Meckling, states a working relation between the party giving the authority (principal), namely the investor, and the party receiving the authority (agency), namely the manager, in a cooperation contract. This difference in interest can be caused or caused by the emergence of information asymmetry (information gap) between shareholders and the organization. Agency theory assumes that all individuals act in their interests. Because of these differences in interests, each party tries to increase its profit for itself.

The relationship between agency theory and earnings quality is the agency relationship that exists between earnings and management. Earnings quality provides information about the situation and condition of a company that the economic impact of transactions that occur will vary between companies as a function of the essential character of the business. The assumption that humans have a selfish nature attached to managers will encourage managers to act more selfishly than act to increase the company's economic value. This will affect the quality of company earnings reported by management which causes management to act freely in carrying out earnings management practices. Conflicts of economic interest occur between shareholders and managers, and this will lead to information asymmetry.

\section{Signaling Theory}

According to Brigham and Houston, a signal is an action taken by a company to provide clues to outsiders about how management views the company's prospect. One way to reduce information asymmetry is by giving signals to outsiders. Information about the company's profit or loss is a signal for investors to estimate the company's performance in the future which will affect their decision on the company. The quality of earnings reflected in the company's financial statements can trigger a reaction to the company's stock price in the market. Through Home Visits signal suggests how a company should give a signal to users of financial statements. This signal is in the form of information about what management has done to realize the owner's wishes. Signals can be promotions or other information stating that the company is better than other companies. Manager provide information through financial statement that apply accounting policies that the produce higher quality earnings because this principle prevent companie from the exaggerating earnings and helps users of the financial statements by presenting profits and asset that is not overstated.

\section{Research Method}

The analysis technique used in this research is multiple regression analysis, which uses SPSS (Statistical Package For Social Science) version 22. In conducting data analysis, several test forms are used, namely the Classical Assumption Test in the form of the Normality Test, Linearity Test, Multicollinearity Test, Autocorrelation Heteroscedasticity Test. The population used in this study were all companies in the Jakarta Islamic Index ( JII) for 2015 - 2019; there are eight companies. In conducting this research, sample selection using a purposive sampling method, which is sampling taken following the stated research objectives. The company criteria used as samples in this study are:

1. Companies listed on the Jakarta Islamic Index (JII) from 2015 to 2019.

2. During the research period, the company did not experience delisting (not listed) from JII.

3. Companies that have published annual reports or financial statements that have been audited by independent auditors during the research year.

4. Companies listed on the Jakarta Islamic Index (JII) for 2015 - 2019 and carry out a dividend policy.

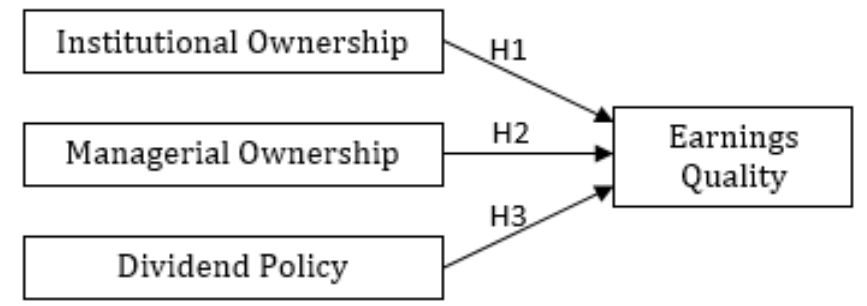

Source: developed for this study (2021)

Figure 1. Research Model 


\section{Result and Discussion}

Table 1. Classical Assumption Test

\begin{tabular}{|c|c|c|c|c|c|c|}
\hline Classical Assumption Test & Provision & & & Result & & \\
\hline $\begin{array}{c}\text { Normality Test } \\
\text { (Kolmogorov-Smirnov) }\end{array}$ & Sig $\geq 0.05$ & & & 0.547 & & \\
\hline Linearity Test & R Square $\leq 0.05$ & & & 0.025 & & \\
\hline \multirow{3}{*}{$\begin{array}{l}\text { Multicollinearity Test } \\
\text { (Tolerance and VIF) }\end{array}$} & \multirow{3}{*}{$\begin{array}{l}\text { Tolerance } \geq 0.10 \text { or } \\
\text { VIF } \leq 10\end{array}$} & $\mathrm{X} 1$ & Tolerance & 0.486 & VIF & 2.057 \\
\hline & & $\mathrm{X} 2$ & Tolerance & 0.486 & VIF & 2.058 \\
\hline & & X3 & Tolerance & 0.996 & VIF & 1.004 \\
\hline $\begin{array}{c}\text { Autocorrelation Test } \\
\text { (Durbin Watson) }\end{array}$ & $\begin{array}{l}\text { DW values between } \\
-2 \text { to }+2\end{array}$ & & & 1.082 & & \\
\hline \multirow{3}{*}{$\begin{array}{l}\text { Heterocedasticity test } \\
\text { (Park Test) }\end{array}$} & \multirow{3}{*}{ Sig $\geq 0.05$} & $\mathrm{X} 1$ & & 0.233 & & \\
\hline & & $\mathrm{X} 2$ & & 0.208 & & \\
\hline & & X3 & & 0.157 & & \\
\hline
\end{tabular}

Source: SPSS Output, 2021 (data reprocessed)

Table 1 insignificance value for normality test is $0.547>0.05$, it is concluded that residual data values are normally distributed. In the R square for the linearity test is $0.025<0.05$, it is concluded that in this study, the occur linearly. The value of the variance inflation factor (VIF) independent variable $<10$, it can be concluded that there is no multicollinearity. The value of DW is 1.082 , based on the decision-making criteria that the DW value between -2 to +2 there is no autocorrelation. Thus it is concluded that the regression model does not occur autocorrelation. The significance value for the park test in this study shows all variables are significance values $>0.05$, and it can be concluded that in this study, heteroscedasticity did not occur.

Table 2. Hypothesis Test Results

\begin{tabular}{clccccc}
\hline Hypothesis Test & \multicolumn{1}{c}{ Provision } & \multicolumn{5}{c}{ Results } \\
\hline \multirow{2}{*}{ T-Test (Partial) } & $\mathrm{t}$-count $) \geq \mathrm{t}-$ table) & $\mathrm{X} 1$ & $\mathrm{t}$ & 3.633 & Sig. & 0.001 \\
\cline { 2 - 7 } & $\mathrm{t}$ table $=2.024$ & $\mathrm{X} 2$ & $\mathrm{t}$ & 4.284 & Sig. & 0.000 \\
\cline { 2 - 7 } & Sig. $\leq 0.05$ & $\mathrm{X} 3$ & $\mathrm{t}$ & 0.705 & Sig. & 0.486 \\
\hline Coefficient determination $\left(\mathrm{R}^{2}\right)$ & R Square & \multicolumn{4}{c}{0.350} \\
\hline
\end{tabular}

Source: SPSS Output, 2021 (data reprocessed)

Based on table 2 for institutional ownership variable obtained t count $3.633>\mathrm{t}$ table 2.024 with a significant number of $0.001<\alpha=0.05$ then $\mathrm{H} 1$ is accepted. Managerial ownership variable obtained t-count $4.284>\mathrm{t}$ table 2.024 with a significant number of $0.000<\alpha=0.05$ then $\mathrm{H} 2$ is accepted. While dividend policy variable obtained t-count $0.705<\mathrm{t}$-table 2.024 with a significant number of $0.486>\alpha=0.05$ then $\mathrm{H} 3$ is rejected. The value of $\mathrm{R}$ square (R2) in this study is 0.350 , meaning that the influence of institutional ownership, managerial ownership, and dividend policy on earnings quality is $35 \%$. In comparison, the remaining $65 \%$ is influenced by variables outside the regression model.

\section{The effect of institutional ownership on earnings quality}

Based on the results of statistical tests on institutional ownership variables that affect earnings quality, it shows that the higher ta level of institutional ownership, the stronger a level of control the carried out by external parties to the company so that agency costs that occur within the company are decreasing. The values of the company can also increase. In addition, with the more substantial level of the control carried out by external parties, it is expected that the level of internal control of the company is also getting better so that the financial statements and reported earnings information will be of higher quality. Rachman and Maghviro (2012) stated that institutional ownership could be an oversight for managing any act performed in the company. Therefore, it is expected that institutional investors can take part in every internal activity of the company so that they can monitor every opportunistic manager's actions.

\section{The effect of managerial ownership on earnings quality}

Managerial ownership affects earnings quality, indicating that the greater managerial ownership of the company, management will tend to try harder for the benefit of shareholders. The greater the managerial ownership will reduce the manager's opportunistic actions. Low managerial ownership will choose accounting methods to increase reported earnings and do not reflect the company's economic condition. Suppose the interests of the owner and agent are aligned due to the managerial ownership mechanism. In that case, the motivation to perform earnings management will decrease so that the reported financial information will produce quality earnings. 


\section{The effect dividend policy on earnings quality}

Based on the statistical test of the dividend policy variable, the results are not significant, this means that dividend policy does not affect earnings quality, which indicates that dividends cannot reflect information about future earnings. Dividend distribution is based not only on management's view that there will be profits in the future but also on maintaining a stable dividend level. This is done because if the company previously always distributed dividends and then stopped distributing dividends, there would be a decline in stock prices.

\section{Conclusion}

Based on the results of the analysis research data analysis that has been carried out, it can be ascertained that the results of each variable are as follows: 1) this study gives a partial influence between institutional ownership on earnings quality which shows that the higher institutional ownership the control which exercised by external partie on the company's is more substantial, so that the agency cost incurred in the company are reduced. The value of the company will increase. 2) The managerial ownership variable has a significant effect on the earnings of quality which indicates the greater the managerial ownership of a company, the management will try to control the shareholders to reduce the opportunistic actions of managers. 3) While the dividend policy variable shows that it is partially insignificant to the quality of the lab, which indicates that dividends cannot reflect information about future earnings

\section{References}

\section{Journal Articles}

Agrawal, A., dan G. Mandelker. 1990. Large shareholders and the monitoring of managers. Journal of Financial and Quantitative Analysis. Vol. 25, No. 2.

Allen F., A. Bernardo dan I. Welch .2000. A theory of dividends based on tax clienteles. Journal of Finance. Vol. 55.

Balsam, S., J. Krishnan, \& J.S. Yang. 2003. Auditor Industry Specialization and Earnings Quality. Auditing: A Journal of Practice \& Theory, 22, 2.

Crutchley, C., and Hansen. 1989. A Test of The Agency Theory of Managerial Ownership, Corporate Leverage, and Corporate Dividend. Financial Management Journal.

Imanta, Dea dan Rutji Satwiko. 2011. Faktor-faktor yang Mempengaruhi Kepemilikan Manajerial. Jurnal Bisnis dan Akuntansi, Vol 13.

Jensen, Michael C. and William H. Meckling. 1976. Theory of the Firm: Managerial Behavior, Agency Costs, and Ownership Structure, Journal of Financial Economics.

Knechel W. Robert, Lasse Niemi, and Stefan Sundgren. 2008. Determinants of Auditor Choice: Evidence from a Small Client Market. International Journal of Auditing, Vol 12.

Lidyah, Rika. 2020. Pengaruh Proteksi Investor Berbasis Kualitas Pemerintahan Terhadap Kualitas Laba: Analisis di Indonesia dan Singapura. Disertasi.

Maghfirotun, Siti. 2010. Pengaruh Kepemilikan Institusional, Aktivitas Komite Audit dan Dewan komisaris independen Terhadap Kualitas Laba. Fakultas Ekonomi. Universitas Indonesia.

Maharani, Meilani Putri. 2015. Pengaruh Kepemilikan Manajerial, Kepemilikan Institusional, Dewan Komisaris Independen, Pertumbuhan Laba, Dan Leverage Terhadap Kualitas Laba (Studi Kasus Pada Perusahaan Manufaktur Yang Terdaftar Di Bei Tahun 2010-2013). Diss. Universitas Negeri Semarang.

Muid, Dul. 2009. Pengaruh Mekanisme Corporate Governance Terhadap Kualitas Laba. Fokus Ekonomi Universitas Diponegoro, Vol 4, No 2.

Nadirsyah dan Fadlan Nur Muharram. 2015. Struktur Modal, Good Corporate Governance dan Kualitas Laba. Jurnal Dinamika dan Bisnis. Vol. 2, 2.

Oktaviani, Rona Naula dan Emrinaldi Nur, Vince Ratnawati. 2015. Pengaruh Good Corporate Governance terhadap Kualitas Laba dengan Manajemen Laba Sebagai Variabel Intervening. Jurnal SOROT. Volume 10,1 .

Puteri, Anggia Paramitha dan Abdul Rohman. 2012. Analisis Pengaruh Investment Opportunity Set (IOS) dan Mekanisme Corporate Governance terhadap Kualitas Laba dan Nilai Perusahaan. Diponegoro Journal of Accounting, Vol 1, No 1.

Rachman, A. A. dan Maghviroh, R. E. 2012. Pengaruh Corporate Social Responsibility, Kepemilikan Manajerial, dan Kepemilikan Institusional Terhadap Nilai Perusahaan. Jurnal Sekolah Tinggi Ilmu Ekonomi Surabaya.

Sarawana, Satya, and Nicken Destriana. 2015. Pengaruh mekanisme tata kelola perusahaan, pendanaan hutang perusahaan, dividen serta ukuran perusahaan terhadap kualitas laba." Jurnal Bisnis dan Akuntansi 17.2.

Sayekti, Nidya Waras. 2020. Permasalahan PT Asuransi Jiwasraya: Pembubaran atau Penyelamatan, Info Singkat: Kajian Singkat Terhadap Isu Aktual dan Strategis.

Shleifer, Andrei, dan Vishny. 1986. Large Shareholders and Corporate Control. Journal of Political Economy, Vol. 94.

Siallagan, Hamonangan dan Machfoedz, M. 2006. Mekanisme Corporate Governance, Kualitas Laba dan Nilai Perusahaan. Disampaikan pada Simposium Nasional Akuntansi (SNA) IX Padang. 
Siregar, S.V. dan Utama, S. 2008. Type of earnings management and the effect of ownership structure, firm size, and corporate-governance practices: Evidence from Indonesia. The International Journal of Accounting, Vol. 43 No. 1.

Smith, Michael P. 1996. Shareholder activism by an institutional investor, evidence for calipers. Journal of Finance. Vol. XLI, No. 1.

Sujoko dan Ugi Soebiantoro. 2007. Pengaruh Struktur Kepemilikan Saham, Leverage, Faktor Intern dan Faktor Ekstern terhadap Nilai Perusahaan. Jurnal Manajemen dan Kewirausahaan. Vol.9, No.1.

Suryani, Indra Dewi, and Raharjda Rahardja. 2010. Pengaruh Mekanisme Corporate Governance dan Ukuran Perusahaan terhadap Manajemen Laba pada Perusahaan Manufaktur yang Terdaftar di BEI. Diss. Universitas Diponegoro.

Books

Ghozali, Imam. 2008. Structural Equation Modeling (Metode Alternatif dengan Partial Least Squares (PLS)), Semarang: Badan Penertbit, Undip.

Ikatan Akuntansi Indonesia-Kompartemen Akuntan Oublik (IAI-KAP), Standar Akuntan Publik, Jakarta: Salemba Empat, 2017.

Kieso, Donald E., Jerry J Weygandt., dan Terry D Warfield. 2009. Intermediate Accounting. 13th Edition. Wiley International Edition.

Mulyadi. 2017. Auditing, Jakarta: Salemba Empat.

Scott, William. 2009. Financial Accounting Theory (5th Edition). Prentice-Hall.

Watts, R. L. Dan J. L. Zimmerman, (1986). Positive Accounting Theory, Prentice Hall International Inc, Englewood Cliffs, NJ, USA.

Website

www.idx.co.id

www.cnbc.co.id 